\title{
Developmental Pattern of Sugar and Amino Acid Transport in the Postnatal Rat Small Intestine
}

\author{
J. F. Fitzgerald ${ }^{[39]}$, S. Reiser, and P. A. Cimristiansen \\ Departments of Pediatrics, Medicine, and Biochemistry, and Gastrointestinal Rescarch Laboratory, Indiana University School of Medicine, \\ and Veterans Administration Hospital, Indianapolis, Indiana, USA
}

\section{Extract}

The transport of two sugars and three amino acids by proximal and distal intestinal segments of 2-, 5-, 10-, 16-, 22-, 26-, 30-, and 70- to 84-day-old rats was investigated. Labeled $\alpha$-methyl-D-glucoside and $\mathrm{D}$-galactose were the sugars and labeled L-valine, L-lysine, and glycine were the amino acids used. The sugars were selected because they are thought to share a common transport system in the adult rat. Conversely, the three amino acids were selected because they appear to have separate transport systems in the adult rat. Intracellular accumulation was the transport variable investigated.

Transport of both sugars and the three amino acids was maximal in early postnatal life (period I; 2-5 days); however, the patterns of decrease in transport to adult levels showed marked variation. The pattern of decrease for both sugars as well as valine was similar, with about $50 \%$ of the total decrease occurring between periods $I$ and $I I$ (10-16 days), about $33 \%$ between periods II and III (22-30 days), and 15-20\% between periods $I I I$ and $I V$ (70-80 days). The well established predominance of the proximal intestine in sugar transport was not observed until period III. Lysine showed a relatively small decrease, $10 \%$, between periods $I$ and $I I$, the largest decrease between periods $I I$ and $I I I$, $56.4 \%$, and a decrease between periods III and $I V$ nearly twice as large as the decrease of any other compound at the comparable age span. Glycine exhibited approximately $70 \%$ of its total decrease between periods $I$ and $I I$. The $15 \%$ decrease in glycine transport between periods $I I$ and $I I I$ was less than one-half that shown by any of the other compounds during the same period.

These developmental data give further support to the thesis of separate transport systems for neutral, basic, and glycine-preferring amino acids.

\section{Speculation}

'This study reveals that protein and carbohydrate digestion end products are maximally transported at or shortly after birth. Further, we believe that significant physiologic data may be obtained from the study of the postnatal developmental patterns of digestive processes.

\section{Introduction}

The optimal protein intake for newborn infants, particularly low birth weight infants, is yet to be defined. Human milk, which is low in protein content, was preferred until Gordon et al. [16] presented data that premature infants fed a half-skimmed cow's milk formula gained weight more rapidly than infants fed an isocaloric formula of human milk. In 1955 Kagan and 
associates [18] suggested that the increased weight gain seen with the above formula was related to the increase in ash-clectrolyte intake rather than to the percentage of protein, carbohydrate, and fat. Since then the protein intake that is most advantageous for premature infants has been the subject of considerable discussion $[1,3,11,15,17,20,21,30,31]$ and raises a basic question, i.e., the effect of age on protein metabolism. Studies of both digestive and transport processes were devised to answer the question whether newborn animals handle protein more efficiently than do adult animals. This report focuses on the study of intestinal transport.

Studies $[5,7,8,12,26]$ indicate that segments of chicken, hamster, rabbit, and rat small intestine are capable of accumulating amino acids and sugars against a concentration gradient at, or shortly after, birth. In this study we set out to characterize the postnatal developmental transport patterns of certain amino acids and sugars. We used three amino acids thought to have separate carrier systems in the adult and two sugars thought to share a common carrier system, so that any maturational carrier system differences might be detected.

\section{Materials and Methods}

Rats of the Wistar strain of both sexes, 2-, 5-, 10-, 16-, 22-, 26-, 30-, and 74- to 84-days-old, were used for the transport studies. The rats were routinely weaned to a standard rat ration at 21 days; therefore, the first four ages represented suckling rats and the remainder represented weaned animals. After the rats were killed by decapitation, the small intestine was quickly removed and then divided into proximal, middle, and distal thirds. The middle portion was discarded. The proximal and distal portions were then split longitudinally and the luminal contents were removed by washing with oxygenated saline. Proximal and distal segments, pooled or subdivided to weigh between $100-500 \mathrm{mg}$, were then placed in $5 \mathrm{ml}$ oxygenated Krebs-Tris buffer (p) $\mathrm{H}$ 7.1) [24], containing $8,000-15,000 \mathrm{cpm} / \mathrm{ml}$ of uniformly labeled $\left({ }^{14} \mathrm{C}\right)$ and nonradioactive sugars and amino acids, to the desired final concentrations. In addition, 5,000-12,000 $\mathrm{cpm} / \mathrm{ml}$ of methoxy $\left({ }^{3} \mathrm{H}\right)$ inulin were added to the medium to measure the extracellular space of the tissue [27]. Segments were incubated at $37^{\circ}$ for $10 \mathrm{~min}$ after which they were washed quickly in saline, blotted, and weighed. Segments then were homogenized in 4 times their weight of $5 \%$ trichloroacetic acid. The homogenate was centrifuged and aliquots of the supernatant were counted in a Tri-Carb liquid scintillation spectrometer [33] in a system containing xylene-dioxane-ethanol $(5: 5: 3)$, naphthalene $(40 \mathrm{~g} /$ liter), 2,5-diphenyloxazole ( $5 \mathrm{~g} /$ liter $)$, and $\mathrm{I}$, 4-bis-2-(5phenyloxazolyl)-benzene $(100 \mathrm{mg} /$ liter $)$. The spectrometer was adjusted to permit $60 \%{ }^{14} \mathrm{C}$ efficiency, $22 \%{ }^{3} \mathrm{H}$ efficiency, less than $0.01 \%{ }^{3} \mathrm{H}$ efficiency on the ${ }^{14} \mathrm{C}$ channel, and $10 \%$ efficiency of the ${ }^{14} \mathrm{C}$ on the ${ }^{3} \mathrm{H}$-channel. Sugar and amino acid transport is expressed as intracellular accumulation which is defined as the millimolar concentration of the sugar or amino acid in the cellular water after a given incubation period, assuming a water content of approximately $80 \%$ of the tissue wet weight [32]. This variable was calculated on the basis of a modification of a formula used by Crane and Mandelstam [10] which now takes the following form: millimolar (cellular water $)=$ (millimolar homogenate supernatant $\times$ homogenate volume) - (extracellular space $\times$ tissue wet weight $\times 0.8 \times$ millinolar medium $) /(1-$ extracellular space $) \times$ (tissue wet weight $\times 0.8)$. The counting rate of each inclividual experiment was mathematically treated so that 10,000 $\mathrm{cpm} / \mathrm{ml}$ were equivalent to the initial concentration of the sugar or amino acid. This permitted the conversion of counts to micromoles of sugar or amino acid from identical experiments having somewhat different initial counting rates.

The source and specific activity of the radioactive compounds used in this study were: uniformly labeled ${ }^{14} \mathrm{C}$ - $\alpha$-methyl-D-glucoside $(3.2 \mathrm{mCi} / \mathrm{mmole}), \quad \mathrm{r}$-valine (14.9 mCi/mmole), r-lysine monohydrocholoride (11.7 $\mathrm{mCi} / \mathrm{mmole})$, and glycine $(15.2 \mathrm{mCi} / \mathrm{mmole})[34]$, uniformly labeled ${ }^{14} \mathrm{C}$-D-galactose $(28.6 \mathrm{mCi} / \mathrm{mmole})$ [35], and methoxy $\left({ }^{3} \mathrm{H}\right)$ inulin $(672 \mathrm{mCi} /$ mmole) $[36]$.

\section{Results}

Previous results have shown that valine, lysine, and glycine do not undergo significant metabolism during the course of the intestinal transport studies [24]. Saunders and Isselbacher [29] have reported that the conversion of galactose to its 1-phosphate by intestine is very slow during the first $10 \mathrm{~min}$ of incubation. On the basis of these results, it is assumed that the sugars and amino acids taken up by the intestine in the present study represent the nonmetabolized forms of these compounds.

Table I shows the effect of age on the intracellular accumulation of $3 \mathrm{~mm} \alpha$-methyl-D-glucose by proximal and distal segments of rat intestine. To describe more clearly and concisely the aging patterns, the means of 
Table I. Effect of age on intracellular accumulation of $3 \mathrm{~mm}$ $\alpha$-methyl-D-glucoside by intestinal segments

\begin{tabular}{|c|c|c|c|c|}
\hline \multirow{2}{*}{$\begin{array}{l}\text { Age, } \\
\text { days }\end{array}$} & \multicolumn{2}{|c|}{$\begin{array}{l}\text { Intracellular accumulation, millimolar } \\
\text { intracellular } \alpha \text {-methy } 1-\mathrm{D} \text {-glucoside } / 10 \mathrm{~min}\end{array}$} & \multicolumn{2}{|c|}{$\begin{array}{c}\text { Percentage of period I } \\
\text { transport }{ }^{2}\end{array}$} \\
\hline & Proximal & Distal & Proximal & Distal \\
\hline $\begin{array}{l}\text { Period I } \\
\quad(2-5)\end{array}$ & $\begin{array}{c}12.78 \pm 0.56^{2} \\
P<0.05^{3}\end{array}$ & $\begin{array}{c}12.48 \pm 0.87 \\
P<0.05\end{array}$ & & \\
\hline $\begin{array}{l}\text { Period II } \\
\quad(10-16)\end{array}$ & $\begin{array}{c}7.14 \pm 0.43 \\
P<0.05\end{array}$ & $\begin{array}{c}9.78 \pm 0.90 \\
P<0.05\end{array}$ & 55.9 & 78.4 \\
\hline $\begin{array}{l}\text { Period III } \\
\quad(22-30)\end{array}$ & $\begin{array}{c}6.09 \pm 0.50 \\
P<0.05\end{array}$ & $\begin{array}{c}4.58 \pm 0.37 \\
P<0.05\end{array}$ & 47.7 & 36.7 \\
\hline $\begin{array}{l}\text { Period IV } \\
\quad(70-80)\end{array}$ & $4.88 \pm 0.45$ & $3.08 \pm 0.35$ & 38.2 & 24.7 \\
\hline
\end{tabular}

${ }^{1}$ Percentage of period I values were obtained by dividing the average transport activity in that period by the average transport activity in period $I$.

${ }^{2}$ Each value represents the mean \pm SEM from at least 15 determinations.

${ }^{3} \mathrm{~A}$ paired or unpaired difference $t$ test was used to determine whether differences in transport values between consecutive time periods were significant; $P$ of 0.05 or less was considered significant.

Table II. Effect of age on intracellular accumulation of $3 \mathrm{~mm}$ galactose by intestinal segments ${ }^{1}$

\begin{tabular}{|c|c|c|c|c|}
\hline \multirow{2}{*}{ Age, days } & \multicolumn{2}{|c|}{$\begin{array}{l}\text { Intracellular accumulation, millimolar } \\
\text { intracellular galactose } / 10 \mathrm{~min}\end{array}$} & \multicolumn{2}{|c|}{$\begin{array}{l}\text { Percentage of period } \\
\text { transport }\end{array}$} \\
\hline & Proximal & Distal & Proximal & Distal \\
\hline$\underset{(2-5)}{\text { Period }} I$ & $\begin{array}{c}6.61 \pm 0.24 \\
P<0.05\end{array}$ & $\begin{array}{c}5.97 \pm 0.41 \\
P<0.05\end{array}$ & & \\
\hline $\begin{array}{l}\text { Period II } \\
(10-16)\end{array}$ & $\begin{array}{c}4.94 \pm 0.33 \\
P<0.05\end{array}$ & $\begin{array}{c}4.42 \pm 0.35 \\
P<0.05\end{array}$ & 74.7 & 74.0 \\
\hline $\begin{array}{l}\text { Period III } \\
\quad(22-30)\end{array}$ & $3.93 \pm 0.28$ & $\begin{array}{c}3.28 \pm 0.24 \\
P<0.05\end{array}$ & 59.4 & 54.9 \\
\hline $\begin{array}{r}\text { Period IV } \\
(70-84)\end{array}$ & $3.26 \pm 0.39$ & $2.53 \pm 0.33$ & 49.3 & 42.4 \\
\hline
\end{tabular}

1 With the exception of the substitution of $3 \mathrm{~mm}$ galactosc for $3 \mathrm{~mm} \alpha$-methyl-D-glucoside in the Krebs-Tris incubation medium, the method used in obtaining and expressing the results are the same as in Table $\mathrm{I}$.

the transport data from the 2-and 5-day-old rats were determined and are presented in the tables as period $I$. Similarly, data from the 10- and 16-day-old rats represent period II; 22-, 26-, and 30-day-old rats, period III; and adult rats, period $I V$. In both intestinal segments intracellular accumulation of $\alpha$-methyl-p-glucose was greatest during period $I$. The accumulation of the sugar in both the proximal and distal segments showed significant decreases between each successive time period, with adult levels being only $38 \%$ (proximal) and $25 \%$ (distal) of that found in period I. After period II, accumulation in the proximal intestine became significantly larger than that in the distal intestine produc- ing the well established gradient of sugar transport activity noted in adult animals [2, 25].

Table II presents the effects of age and intestinal location on the intracellular accumulation of $3 \mathrm{~mm}$ D-galactose after a 10-min incubation. Over the age span studied, maximal transport again occurred in period $I$ and no segmental differences were noted until the 22nd day when proximal accumulation became significantly greater than distal accumulation. Again, the pattern is one of a steady decrease of transport as a function of age resulting in a composite adult galactose accumulation approximately $45 \%$ of that found in period $I$.

The effects of age on the transport of $1 \mathrm{~mm}$ L-valine are shown in Table III. Maximal accumulation occurred in both segments in period $I$ followed by a progressive decrease of about $50 \%$ to adult values in a manner similar to that seen with the sugars. Valine accumulation in period III reached values not signifcantly different from those found in adult rats. In contrast to the sugars, valine accumulation in the proximal and distal segments remained statistically equivalent as a function of age.

The pattern of lysine intracellular accumulation as a function of age (Table IV) showed a distinct difference from those of the compounds studied previously. Lysine accumulation did not decrease between periods $I$ and $I I$, resulting in a broad maximum of lysine transport between the $2 \mathrm{nd}$ and 16 th day. The greatest decrease in activity occurred between periods $I I$ and III followed by a smaller decrease between periods III and $I V$ to adult levels which were about $50 \%$ lower than those in period $I$. No significant segmental variations in lysine transport were observed over the time periods studied.

Table III. Effect of age on the intraccllular accumulation of 1 m valine by intestinal segments ${ }^{1}$

\begin{tabular}{|c|c|c|c|c|}
\hline \multirow{2}{*}{ Age, day } & \multicolumn{2}{|c|}{$\begin{array}{l}\text { Intracellular accumulation, millimolar } \\
\text { intracellular valine } / 10 \mathrm{~min}\end{array}$} & \multicolumn{2}{|c|}{$\begin{array}{c}\text { Percentage of period } \\
\text { transport }\end{array}$} \\
\hline & Proximal & Distal & Proximal & Distal \\
\hline $\begin{array}{l}\text { Period I } \\
\quad(2-5)\end{array}$ & $\begin{array}{c}4.29 \pm 0.29 \\
P<0.05\end{array}$ & $\begin{array}{c}4.66 \pm 0.26 \\
P<0.05\end{array}$ & & \\
\hline $\begin{array}{l}\text { Period II } \\
\quad(10-16)\end{array}$ & $\begin{array}{c}3.42 \pm 0.26 \\
P<0.05\end{array}$ & $3.30 \pm 0.22$ & 79.7 & 70.8 \\
\hline $\begin{array}{l}\text { Period III } \\
\quad(22-30)\end{array}$ & $2.41 \pm 0.16$ & $2.86 \pm 0.15$ & 56.2 & 61.4 \\
\hline $\begin{array}{l}\text { Period IV } \\
\quad(70-84)\end{array}$ & $2.10 \pm 0.15$ & $2.43 \pm 0.22$ & 49.0 & 52.1 \\
\hline
\end{tabular}

${ }^{1}$ With the exception of the substitution of $1 \mathrm{~mm}$ valinc for $3 \mathrm{~mm}$ $\alpha$-methyl-D-glucoside in the Krebs-Tris incubation medium, the method used in obtaining and expressing the results are the same as for Table 1 . 
The largest intracellular accumulation of $3 \mathrm{~mm} g \mathrm{gly}-$ cine was also noted during period $I$ (Table V). With glycine, the proximal and distal segments exhibited distinct patterns of decrease as a function of age. In the proximal segment the entire decrease to adult levels occurred between periods $I$ and $I I$, with no significant differences in glycine accumulation evident in successive periods. Glycine transport in the distal segment decreased more gradually, with significant difference noted between periods $I$ and $I I$ and between periods $I I$ and $I I I$. During period $I I$, glycine accumulation in the distal segment was significantly greater than glycine accumulation in the proximal segment. The composite level of glycine accumulation fell $46 \%$ over the age range studied.

Although all the sugars and amino acids studied showed the largest transport in period $I$ followed by progressive decreases to adult levels, the pattern of decrease varied. Table VI illustrates these patterns more distinctly by expressing the percentage of the total decrease occurring during each consecutive period for each sugar and amino acid. Proximal and distal transport were considered collectively in the construction of this table. The pattern of decrease for both sugars as well as valine was similar, with about $50 \%$ of the total decrease occurring between periods $I$ and $I I$, about $33 \%$ between periods $I I$ and $I I I$, and $15-20 \%$ between periods $I I I$ and $I V$. Lysine, however, showed little decrease between periods $I$ and $I I(10 \%)$, the largest decrease between periods $I I$ and III (56.4\%), and a decrease between periods III and $I V$ nearly twice as large as the decrease of any of the other compounds during the same age range. Glycine exhibited nearly $70 \%$ of its total decrease between periods $I$ and $I I$. The decrease in glycine transport between periods $I I$ and $I I I$ was $15 \%$, which was less than one-half that shown by any of the other compounds during the same period.

\section{Discussion}

In agreement with previous studies [7, 8], steady state transport peaks for both amino acids and sugars were observed immediately after birth. The patterns of decrease for the sugars and amino acids as a function of age, however, were different and these differences appeared to be related to the specificity of the carriers which are assumed to mediate the active transport of these nutrients. The patterns of decrease for the sugars were essentially identical (Table VI). On the basis of kinetic studies which showed that galactose was a competitive inhibitor of $\alpha$-methyl-1-glucose accumulation
Table IV. Effect of agc on intraccllular accumulation of $1 \mathrm{~mm}$ lysine by intestinal segments ${ }^{1}$

\begin{tabular}{|c|c|c|c|c|}
\hline \multirow[t]{2}{*}{ Age, days } & \multicolumn{2}{|c|}{$\begin{array}{l}\text { Intracellular accumulation, millimolar } \\
\text { intracellular lysine } / 10 \mathrm{~min}\end{array}$} & \multicolumn{2}{|c|}{$\begin{array}{l}\text { Percentage of period } \\
\text { transport }\end{array}$} \\
\hline & Proximal & Distal & Proximal & Distal \\
\hline $\begin{array}{l}\text { Period I } \\
(2-5)\end{array}$ & $2.93 \pm 0.27$ & $2.75 \pm 0.27$ & & \\
\hline $\begin{array}{c}\text { Period II } \\
(10-16)\end{array}$ & $\begin{array}{c}2.62 \pm 0.20 \\
P<0.05\end{array}$ & $\begin{array}{c}2.77 \pm 0.39 \\
P<0.05\end{array}$ & 89.4 & 100.7 \\
\hline $\begin{array}{l}\text { Period III } \\
\quad(22-30)\end{array}$ & $1.97 \pm 0.19$ & $1.85 \pm 0.15$ & 67.2 & 67.3 \\
\hline $\begin{array}{l}\text { Period IV } \\
\quad(70-84)\end{array}$ & $1.62 \pm 0.14$ & $1.29 \pm 0.13$ & 55.3 & 46.2 \\
\hline
\end{tabular}

${ }^{1}$ With the exception of the substitution of $1 \mathrm{~mm}$ lysine for $3 \mathrm{~mm}$ $\alpha$-methyl-D-glucoside in the Krebs-Tris incubation medium, the method used in obtaining and expressing the results are the same as for Table I.

Table $V$. Effect of age on intraccllular accumulation of $3 \mathrm{~mm}$ glycine by intestinal segments

\begin{tabular}{|c|c|c|c|c|}
\hline \multirow{2}{*}{ Age, days } & \multicolumn{2}{|c|}{$\begin{array}{l}\text { Intracellular accumulation, millimolar } \\
\text { intracellular glycine } / 10 \mathrm{~min}\end{array}$} & \multicolumn{2}{|c|}{$\begin{array}{c}\text { Percentage of period } \\
\text { transport }\end{array}$} \\
\hline & Proximal & Distal & Proximal & Distal \\
\hline $\begin{array}{l}\text { Period } I \\
(2-5)\end{array}$ & $\begin{array}{l}6.31 \pm 0.43 \\
P<0.05\end{array}$ & $\begin{array}{c}5.36 \pm 0.69 \\
P<0.05\end{array}$ & & \\
\hline $\begin{array}{l}\text { Period II } \\
\quad(10-16)\end{array}$ & $3.32 \pm 0.20$ & $4.22 \pm 0.24$ & 52.6 & 70.8 \\
\hline $\begin{array}{l}\text { Period III } \\
\quad(22-30)\end{array}$ & $3.04 \pm 0.33$ & $3.46 \pm 0.18$ & 48.2 & 58.0 \\
\hline $\begin{array}{l}\text { Period IV } \\
\quad(70-84)\end{array}$ & $2.69 \pm 0.17$ & $2.79 \pm 0.37$ & 42.6 & 46.8 \\
\hline
\end{tabular}

${ }^{1}$ With the exception of the substitution of 3 mm glycine for $3 \mathrm{~mm}$ $\alpha$-methyl-D-glucoside in the Krcbs-Tris incubation medium, the method used in obtaining and expressing the results are the same as for Table 1 .

Table VI. Relative rate of decrease of intracellular accumulation as a function of consecutive time periods

\begin{tabular}{cccccc}
\hline & \multicolumn{5}{c}{ Percentage of total decrease of transport' } \\
\cline { 2 - 5 } & $\begin{array}{c}3 \mathrm{mM} \\
\text { Decrease between periods } \\
\begin{array}{c}\alpha \text {-Mcthyl- } \\
\text { D-gluco- } \\
\text { side }\end{array}\end{array}$ & $\begin{array}{c}3 \mathrm{~mm} \\
\text { Galactose }\end{array}$ & $\begin{array}{c}1 \mathrm{~mm} \\
\text { Valine }\end{array}$ & $\begin{array}{c}3 \mathrm{mM} \\
\text { Glycine }\end{array}$ & $\begin{array}{r}1 \mathrm{~mm} \\
\text { Lysine }\end{array}$ \\
\hline$I$ and $I I$ & 48.2 & 47.5 & 50.5 & 69.7 & 10.0 \\
$I I$ and $I I I$ & 36.1 & 31.6 & 32.8 & 15.3 & 56.4 \\
$I I I$ and $I V$ & 15.7 & 20.9 & 16.7 & 15.0 & 33.6 \\
\hline
\end{tabular}

${ }^{1}$ The composite transport value for each sugar and amino acid for each period was obtained by averaging the proximal and distal values. The total decrease of transport was obtained by subtracting the transport of each sugar or amino acid in period $I V$ from that found in period $I$. The percentage of the total decreases between the consecutive age periods was determined by dividing the decrease between consecutive periods by the overall decrease between periods $I$ and $I V$. 
in intestinal slices from the hamster [4], the carrier mediating the active transport of these sugars appears to be the same. The three amino acids used in this study are generally considered to represent three of the four specific pathways of amino acid transport in mammalian intestine [28]. Valine, a representative of the neutral amino acid pathway, lysine, a representative of the basic amino acid pathway, and glycine, with affinity for a pathway utilized by imino acids and neutral amino acicls without lipophilic side chains, showed marked differences in their maturation patterns. The differences in the effect of age on the transport of these amino acids provides additional evidence that independent transport pathways or carriers are involved. A similar aging pattern shown by two actively transported compounds, however, is not necessarily an indication that they are transported by the same pathway. For example, although the aging patterns for the sugars and valine were very similar, there is abundant evidence that sugars and amino acids are not transported by the same pathways $[6,9,19,24]$.

Although the high level of protein biosynthesis and the energy required for this synthesis can explain the necessity for an increased transport of amino acids and sugars in young animals, the manner in which the accelerated transport is mediated should be considered. Valine transport in the 2-day-old rats was found to be inhibited by leucine and galactose and dependent on the presence of sodium ions [13], inclicating that the characteristics of the valine carrier system in young animals are similar to those found in adult animals [22, 23]. Further evidence that the increased transport in young animals was not due to the transient presence of structurally modified transport carriers which may bind valine more efficiently comes from kinetic studies reporting that apparent $K_{m}$ for valine accumulation in 2-day-old rats and in adult rats was the same [26]. It appears, rather, that the increased transport in young animals represents a locationally nonspecific increase in the number of transport carriers [7]. This contention is supported by the clistribution of the transport activity of the sugars in the proximal and clistal intestine as a function of age. During the first two age periods, there was no difference in sugar transport between the proximal and distal intestine. After this time the transport activity in the distal intestine decreased more rapidly than the activity in the proximal intestine resulting in the distribution pattern of sugar transport observed in adult animals $[2,25]$. The failure to observe a difference in amino acid transport activity between the proximal and distal segments as a function of age is attributed to the presence of peak activity for amino acid transport in the midintestine [14, 25].

\section{Summary}

The transport of two sugars, labeled $\alpha$-methyl-D-glucoside and $\mathrm{D}$-galactose, and three amino acids, labeled $\mathrm{L}$-valine, $\mathrm{L}-\mathrm{lysine}$, and glycine, by proximal and distal intestinal segments of 2-, 5-, 10-, 16-, 22-, 26-, 30-, and 70- to 84-day-old rats was investigated. The sugars were selected because they are thought to share a common transport system in the adult rat. Conversely, the three amino acids were selected because they seem to have separate transport systems in the aclult. Intracellular accumulation was the transport variable investigated.

Transport of both sugars and the three amino acids was maximal in the early postnatal period (2-5 days). The three amino acids showed distinct variation in their developmental transport patterns whereas the sugars had similar patterns.

These developmental data give further support to the thesis of separate transport systems for neutral, basic, and glycine-preferring amino acids.

\section{References and Notes}

1. Babson, S. G., ANi Bramian.L, J. L.: Diet and growth in the premature infant. J. Pediat., 74: 890 (1969).

2. Bakrr, R. D., SFari.f, G. W., and NeNn, A. S.: Glucose and sorbose absorption at vaxious levels of rat small intestine. Amer. J. Physiol., 200: 301 (1961).

3. Barness, L. A., Cornely, D. A., Valyasevi, A., and Gyorgy, P.: Comparison of prematures fed high and low protein diets. Amer. J. Dis. Child., 9f: 480 (1957).

4. BArNeT, J. E. G., Jarvis, W. T. S., AND MUNdAY, K. A.: Structural requirements for active intestinal sugar transport: the involvement of hydrogen bonds at C-1 and C- 6 of the sugar. Biochem. J., 109:61 (1968).

5. BAT, E. R., AND SChachTrR, D.: Developmental pattem of some intestinal transport mechanisms in newborn rats and mice. Amer. J. Physiol., 216: 1064 (1969).

6. Binghà, J. K., Newey, H., ANd SMYTh, D. H.: Specificity of inhibitory effects of sugars on intestinal amino acid transfer. Biochim. Biophy's. Acta, 120: 314 (1966).

7. Bogier, P. H., ANd Hanes, I. A.: Functional development of active sugar transport in the chick intestine. Amer. J. Physiol., 267: 37 (1964).

8. BuTT, J. H., JR., AND WrLson, T. H.: Development of sugar and amino acid transport by intestine and yolk sac of the guinea pig. Amer. J. Physiol., 215: 1468 (1968).

9. Chez, R. A., Schulitz, S. G., and Curran, P. li.: Eiffect of sugars on transport of alanine in intestine. Science, 153: 1012 (1966).

10. Crane, R. K., and Mandelstam, P.: The active transport of sugars by various preparations of hamster intestine. Biochim. Biophys. Acta, 45: 477 (1960). 
11. DAvinson, M. I)., LeviNe, S. Z,, BAulr, C. H., AND DANN, M.: feceling studies in premature infants. J. Pediat., 70: 695 (1967).

12. Derr.y, J. J., STrauss, E. W., and Wison, T. H.: The development of structure and transport systems of the fetal rabbit intestine. Develop. Biol., 13:370 (1965).

13. Fitzgerdid, J. F., Rfistr, S., And Cintistansia, P. A.: Unpublished results.

14. Grokcir, M. J., AND BAKER, R. D.: Lptake of amino acids by rat small intestine: patterns along intestine for different transport groups. Physiologist, $8: 171$ (1965).

15. Goldman, H. I., Freudrammi, R., Holland, B., aNd KareIrrz, S.: Clinical effects of two different levels of protein intake on low-birth-weight infants. J. Pediat., 7f: $88 \mathrm{l}$ (1969).

16. Gornox, H. H., Lrvine, S. Z., ANo MeNamarA, H.: Feeding of premature infants, a comparison of human and cow's milk. Amer. J. 1)is. Child., 73: 442 (1947).

17. Hor.', L. E., JR.: The protein requixement of infants. $y$. Pediat., 5f: $496(1959)$.

18. Kagan, 13. M., Hrss, J. H., Ludeen, l., Shafer, K., Parker, J. B., AND STroni, C.: Fecding premature infants-a comparison of various milks. Pediatrics, $15: 373$ (1950).

19. Musck, B. G.: Amino acid transport by the small intestine of the rat. Fvidence against interactions between sugars and amino acids at the camier level. Biochim. Biophys. Acta, 156: $192(1968)$.

20. Omans, W. B., Barkess, I. A., Rosk, C. S., AND Crorgi, P.: Prolonged feeding studies in premature infants. J. Pediat., 59: 951 (1961).

21. Phaus, J. B., Githlemax, I. F., Scmmerzler, E., and BruNETT, N.: Protein levels in serum of premature infants fed diets varying in protein concentrations. Pediatrics, 30: 622 (1962).

22. Reiser, S., AND Christiansex, P. A.: Intestinal transport of amino acids studied with r-valine. Amer. J. Physiol., 208: 914 (1965)

23. Reiser, S., And Christinnsin, P. A.: Intestinal transport of valine as affected by ionic environment. Amer. J. Physiol., 212: 1297 (1967).
24. Ristik, S., ANi) Curmitansin, P. A.: Intestinal transport of amino acids as affected by sugars. Amer. J. Physiol., 216: 915 (1969).

25. Retser, S., and Christinnsin, P. A.: A cross-inhibition of basic amino acid transport by neutral amino acids. Biochim. Biophys. Acta, 183:611 (1969).

26. Reiser, S., Fitzgfrald, J. F., and Christinnsfo, P. A.: Kinetics of the accelerated intestinal transport in 2-day-old rats Biochim. Biophys. Acta, 203: 351 (1970).

27. Rosenbre, I. E., Downixg, S. T., and Srgar, S.: The extracellular space estimation in rat kidney slices using $C^{1 *}$ saccharides and phlorizin. Amer. J. Physiol., 202: 800 (I962).

28. SAunders, S. J., AND Isseibacilir, K. J.: Inhibition of intestinal amino acid transport by hexoses. Biochim. Biophys. Acta, 102: $397(1966)$.

29. SAundres, S. J., ANi Issribachirk, K. J.: Intestinal absorption of amino acids. Gastroenterology, 50: 586 (1966).

30. Siyphoman, S. E., Boyers, A., Kogut, M. D., and Hort, L. E., $J_{R}$.: The protein requirement of the premature infant. I. The effect of protein intake on the retention of nitrogen. J. Pediat., 7 t: 872 (1969).

31. SNymfrnax, S. E., AND HolT, I. E., Jk.: The effect of high caloric fecting on the growth of premature infants. J. Pediat., $58: 237$ (1961)

32. Splictr, R. P., ANo SAmir, A. H.: Intestinal absorption of I.-phenylalanine in vitro. Amer. J. Physiol., 200: 501 (1961).

33. Packard Instruments Company, Downers Grove, Ill.

34. Amersham/Searle Corporation, Arlington Heights, Ill.

35. International Chemical and Nuclear Corporation.

36. New England Nuclear, Boston, Mass.

37. The authors are indebted to $\mathrm{Mr}$. ' $\Gamma$. Hamiter for his technical assistance.

38. Supported in part by Public Hcalth Service Research Grants nos. AM 0.5932 and AM 5223 from the National Institutes of Health, and Rilcy Memorial Association Project no. 69-3.

39. Requests for reprints should be addressed to: J. F. FrizGERAID, M.D., Department of l'ediatrics, Section of Gastrocnterology, Indiana University School of Mcdicine, $1100 \mathrm{~W}$. Michigan Strect, Indianapolis, Indiana 46202 (USA).

40. Accepted for publication February 2, 1971. 